Pobrane z czasopisma Annales H - Oeconomia http://oeconomia.annales.umcs.pl Data: 26/04/2023 07:17:50

DOI:10.17951/h.2015.59.3.161

\begin{tabular}{lcc}
\hline \multicolumn{3}{c}{ A N N A L E S } \\
UNIVERSITATIS & MARIAE CURIE-SKŁODOWSKA \\
LUBLIN - POLONIA & \\
VOL. XLIX, 3 & SECTIOH H \\
\hline
\end{tabular}

University of Rzeszów, Faculty of Economics, Department of Marketing and Entrepreneurship

TOMASZ SURMACZ

toms@univ.rzeszow.pl

Supply Chain Relationships in the Context of Innovative Processes

Relacje w łańcuchach dostaw w kontekście działań innowacyjnych

Keywords: Supply Chain Management, integration, collaboration, innovation.

Słowa kluczowe: zarządzanie łańcuchami dostaw, integracja, współpraca, innowacja.

JEL Code: M16

\title{
Introduction
}

Innovation is a popular topic for companies. It has been believed to be a critical factor for organisational development. According to Martin Christopher, modern competition does not take place between individual companies but between supply chains. Hence, the challenge is to find innovative solutions at the supply chain level. Supply Chain Management (SCM) practices are considered to be in the fore-front of modern organizational advancements.

\section{Supply Chain Management}

Supply Chain Management is the sequence of processes and activities involved in the complete sourcing, manufacturing and distribution cycle which is known as the supply chain. 
Supply Chain Management started to develop at the beginning of 1980s. But the foundation of this idea were the results of research published at least twenty years earlier. However, the first time the term "Supply Chain Management" appeared in the literature is 1982. R. Olivier and M. Webber are considered to be the creators of this concept. They wrote about supply chains in the context of the role that top management of multinational corporations should play in resolving conflicts for different functional areas of organizations that results in uncoordinated flow of products, information and financial resources. According to other sources, the term supply chain management was introduced (also in 1982) by K. Oliver (consultant in Booz Allen Hamilton). The concept has been extended by J.B. Houlihan in 1985 in an article indicating the benefits of information sharing and coordination in supply chains (Pramatari, 2007, p. 210).

From the beginning of the 1990s, it became a common conviction that integration of business partners should be in the centre of the supply chain management. Cooperation in the network occurs when two or more companies share responsibility for joint planning, management, and leadership as well as measurable action effects. One of the most often used definitions of SCM was presented by Lambert: "Supply chain management is the integration of key business processes from end user through original suppliers that provide products, services, and information that add value for customers and other stakeholders" (Lambert et al., 1998, pp. 1-19).

Over the years there were discussions whether SCM is a concept, technique or a strategy. At the beginning of the 21st century it started to be viewed as a philosophy. For example Mentzer understands SCM this way stressing the following:

- systemic approach to viewing of the supply chain as a whole and management of the overall flow from suppliers to customers,

- strategic orientation towards cooperation to synchronize activities at operational and strategic level,

- focus on customer value and satisfaction (Mentzer, 2001, pp. 1-25).

Supply Chain Management has changed the way we look at competition as it is more and more acknowledged that competition takes place between supply chains rather than between individual companies.

\section{Complexity and Risk as Supply Chain Challenges}

Supply Chain Management can offer multiple benefits and there are numerous examples of superior performance achieved by companies adopting this approach. But it can also be very challenging. One of the biggest problems concerning managing supply chains can be their complexity. Complexity in supply chains grows, as customer requirements increase or change, competitive environment transforms, and as companies in supply chains adopt new technologies or launch new products. Also globalization and new market possibilities make managing supply chains more difficult and complex. 
Complexity can be observed in different forms and origins:

- static complexity (related to the connectivity and structure of the subsystems involved in the supply chain - companies, business functions and processes);

- dynamic complexity (results from the operational behaviour of the system and its environment);

- decision-making complexity (involves both static and dynamic aspects of complexity).

Because of the growing complexity, it is said that SCM is about managing the complexity of the supply chain (Serdarasan, 2013, pp. 533-540). For all involved companies, the increase in the degree of complexity may worsen supply chain performance. Hence, the competitive advantage will increasingly derive from complexity management capabilities. A study conducted by A.T. Kearney states that companies can increase their EBIT by 3-5\% if they start to actively manage complexity (Aelker et al., 2013, pp. 79-84).

According to literature, supply chain complexity depends on several drivers: the number of supplier relationships that must be managed, the degree of differentiation among these suppliers in terms of size, technology, etc., the delivery lead time and reliability of suppliers, the extent of global sourcing, and the level of inter-relationship among the suppliers (Caridi et al., 2010, pp. 372-383).

The more complex supply chains are, the greater the possibility of disruptions. Therefore, some researchers point out supply chain sensitivity as one of the greatest challenges. But in addition to disruptions which can be severe but are quite rare, there are at least 6 major types of supply chain risks that occur regularly: supply risks, process risks, demand risks, intellectual property risks, behavioural risks, and political/social risks (Tang et al., 2008, pp. 12-27).

It is commonly accepted that risks can be assessed and to some extent mitigated which is why the term Supply Chain Risk Management was coined. SCRM definition from Tang (2006, pp. 451-488) explains it as "the management of supply chain risk through coordination or collaboration among the supply chain partners so as to ensure profitability and continuity".

There are 2 main types of risk to be included in a risk management plan: external and internal risks. External risks can be driven by events alongside the supply chain. There are 5 main types of external risks: demand risks, supply risks, environmental risks, business risks, physical plant risks. Internal risks are within companies' control. They are: manufacturing, business risks, planning and control, mitigation and contingency, cultural risks.

Both the complexity and risk can be managed in supply chains due to the increased levels of information sharing and collaboration. 


\section{Relationships as Innovations in Supply Chains}

"Innovation is the embodiment, combination, and/or synthesis of knowledge in novel, relevant, valued new products, processes, or services" (Leonard et al., 1999, p. 7). The cited definition suggests that Supply Chain Management itself can be called an innovation. And it certainly is. Although, as stated before, the concept has been rapidly developing for the last 30 years, still many companies consider it a modern approach. Definitely a shift from looking at logistics processes from a single company's point of view to a supply chain perspective is innovative and still offers a wide range of possibilities to implement new solutions and improve performance. And organizations can develop innovations across the entire supply chain continuum. Supply chain innovations are important for companies of all sizes, although they are often analysed in terms of large or multinational corporations. And innovations may take place at different levels. They might be implemented on the design level or at the process level. When talking about innovations, they are usually analysed from technological point of view. Technology may offer (and already has offered) great opportunities for Supply Chain Management and supply chains are changing as a result of new technology adoption, but it has to be seen that new technologies develop as a way to handle changing relationships in supply chains.

The key areas of innovative activity include collaboration and process integration. Supply Chain Management consists of collaborative relationships between buyers and suppliers, which involve integration and adaptation between the parties. Exchange of information has been traditionally involved in buyer-seller dyads but SCM has changed the perspective and the level of collaboration. Companies had to collaborate to some extent to trade with each other but it is the collaborative culture which is the foundation of SCM that has enabled significantly better performance for all parties. It evolved from adversarial to collaborative relationships with partners, including distributors, third-party logistics and contract manufacturers, and governmental and nongovernmental organizations. Adversarial supply chains have no place in the future. SCM requires a movement away from arms-length relationships toward partnership style relations.

The concept of an integrated supply chain develops dynamically. Non-integrated supply chains can cause problems for customers such as: excessive inventory, incompleteness of the supply, lack of timeliness of deliveries. The suppliers also experience difficulties associated with uncertainty and the lack of adequate information about the activities and the needs of the customers. This usually results in a lower level of customer service, higher costs and lower profits. True cooperation between enterprises (cross-enterprise collaboration) occurs when two or more companies voluntarily agree to integrate human resources, both financial and technical, to create a new, more efficient, effective, or appropriate business model. Through such cooperation, the participating companies form a common policy and integrate operational processes on a voluntary basis to eliminate duplication or inefficient action for maximum productivity. As a result, there may appear a form which is often called an extended enterprise. 
Trust and commitment are most often depicted in literature as characteristics of the strength of relationship between companies. Trust is essential, if we are talking about enhanced cooperation and exchange of information.

\section{Trends and Predictions about Future SCM Innovations}

Trends and challenges in SCM are interrelated. The most often predicted trend for the coming years are growing and changing customer expectations, networked economy, increased cost pressures, globalization, sustainability pressures, and new technologies. Here is an example list of trends identified in 2011':

- Increasing use of technology to mobilise innovation, collaboration and transparency in supply chains.

- Interoperability of systems collecting data.

- Moving beyond individual company data to information that can be aggregated to give insight into sectorial and regional supply chain trends.

- Remove barriers to collaboration internally and build understanding - shift to conversations with wider/different parts of the organisation. Multi-disciplinary teams.

- Multi-Stakeholder Initiatives (MSIs) - Companies of the future will need to work with more varied organisations to plan for uncertainty and align to meet big global development goals.

- Greater cooperation and collaboration between businesses of all sizes.

After almost 4 years after this publication, all of these trends seem to be valid and actions of companies wanting to respond to these trends are necessary and viable. What is important is the fact that not only technological point of view is presented here. Technologies are important but the focus should be on greater collaboration and trust among organizations.

The current tendency is that supply chains should be demand driven or/and customer driven. Developments in supply chains are influenced by what customers need and want, including 2 : reduced costs, higher and verifiable quality, reduced lead times, reduced process variability, increased flexibility and agility, reduced risk to consumers, responsiveness to consumer's needs and wants, and assimilation of new technologies. This means ability to react for some rapid changes in real time. Supply Chain Management will need to become more agile and flexible. Many authors refer to "agile supply chains" as a key to meet supply chain challenges and mitigate risks in the future. Being able to maximize supply chain flexibility and manage various supply chain configurations have become compulsory for today's supply chain managers. Companies will

\footnotetext{
1 http://www.sedexglobal.com/wp-content/uploads/2011/06/Sedex-Briefing-Future-Supply-ChainQ3-2014-Final1.pdf

2 http://media.apics.org/omnow/Seeing\%20the\%20Future\%200f\%20Supply\%20Chains.pdf
} 
need flexibility to adapt to short-term disruptions or they will be unable to effectively forecast. Organizational changes give companies flexibility to change sourcing, manufacturing, and distribution quickly to balance supply and demand.

The survey Innovations that Drive Supply Chains conducted by MHI and Delloite included more than 450 respondents and revealed two major barriers to development and adoption of supply chain innovations: talent shortage and continued focus on cost reductions ${ }^{3}$. And three more emerging innovation areas were identified as the ones going to be dominant in the future: sustainability, mobile and machine-to-machine (M2M) technologies, 3D printing (Additive Manufacturing). Out of these three trends $3 \mathrm{D}$ printing has a potential but its future impact is difficult to predict. But the other two innovations are becoming more popular.

Supply Chain Management is changing in many areas, since the business environment is volatile and skills required from employers tomorrow may be different from today. Skilled labour and talent management can be essential for the success of supply chains in the future. In the report Seeing the Future of Supply Chains authors predict that building knowledge supply chains and knowing how to teach, train and cultivate wisdom may be crucial for creating competitive advantage ${ }^{4}$. To be able to capitalize on the latest innovations, companies need supply chain employers with right skills as well as supply chain knowledge and experience. According to a report from 2013 prepared by Handfield, talent shortages in logistics are considered one of the most important challenges in the coming years (Handfield, 2013). Shortages can be seen at both the operational level as well as in the planning and controlling function. About $70 \%$ of the respondents of this study experience a shortage of skilled labour.

In the same report sustainability pressure has emerged as a very serious trend. Already more than 55\% of the respondents stated that green issues are part of their logistics strategy. There is a great deal of uncertainty in the implementation of Green Supply Chain Management (or Sustainable Supply Chain Management) strategies, especially in terms of measurement systems.

In a report by MIT Sloan and The Boston Consulting Group from 2013 it is stated that two thirds of surveyed managers rate social and environmental issues as "significant" or "very significant" among their sustainability concerns. But only $10 \%$ say their companies fully tackle these issues and only $40 \%$ report that their organisations are largely addressing them ${ }^{5}$.

It is estimated that only $20 \%$ of supply chain members today have necessary information available to run their businesses effectively. Big Data has a great potential to improve the situation by helping to identify areas where adjustments are needed

${ }^{3}$ https://www.mhi.org/publications/report\#download; 2014 MHI Annual Industry Report - Innovations That Drive Supply Chains.

$4 \mathrm{http} / /$ media.apics.org/omnow/Seeing\%20the\%20Future\%20of\%20Supply\%20Chains.pdf

5 MIT Sloan Management Review and The Boston Consulting Group, 2013. Sustainability's Next Frontier. http://sloanreview.mit.edu/projects/sustainabilitys-next-frontier/ 
and processes can be improved ${ }^{6}$. One of the biggest trends which will probably shape the future of supply chains is the Internet of Things. It is believed to improve demand forecasting and reduce volatility as intelligent devices will inform about the need to replenish. Technologies such as Big Data might have the potential to transform entire operations in some supply chains (especially large and complex ones). Radio-frequency identification (RFID) and other digital technologies lead to new possibilities in supply chain visibility and possibilities of process automation. New technologies enable supply chain members to interact in joint management in the flow of goods and information.

\section{Conclusions}

Companies that acknowledge supply chain as a strategic asset achieve $70 \%$ higher performance according to Global Supply Chain Survey conducted by PwC in 2013. And $45 \%$ of the participants (503 companies) acknowledge that supply chain is seen as a strategic asset in their company ${ }^{7}$. Relationships are the dominant issue in SCM. By placing relationships at the centre of supply chain management, it is possible to create a more collaborative and effective dynamic structures. And no innovations would be possible in SCM without trust, openness, collaboration culture, and information sharing. The new upcoming innovations in the sphere of SCM stem from the developing trends and include mainly: sustainability issues (especially "greening" of supply chains), Big Data and new technologies as well as knowledge and talent management in supply chains.

\section{References}

1. Aelker J., Bauernhansl T., Ehm H., Managing complexity in supply chains: A discussion of current approaches on the example of the semiconductor industry, Procedia CIRP, 7, 2013.

2. Caridi M., Crippa L., Perego A., Sianesi A., Tumino A., Do virtuality and complexity affect supply chain visibility?, International Journal of Production Economics, Vol. 127, No. 2, 2010. http://dx.doi.org/10.1016/j.ijpe.2009.08.016

3. Handfield R.B., Straube F., Pfohl H.-Ch., Trends and Strategies in Logistics and Supply Chain Management: Embracing Global Logistics Complexity to Drive Market Advantage, Hamburg: 2013; http:// www.supplychain247.com/paper/embracing_global_logistics_complexity_to_drive_market_advantage/executive_education

4. http://2014.internationaltransportforum.org/supply-chains-future\#sthash.KtoyZRgG.dpuf

5. http://media.apics.org/omnow/Seeing $\% 20$ the $\% 20$ Future $\% 20$ of $\% 20$ Supply $\% 20$ Chains.pdf

6. http://media.apics.org/omnow/Seeing $\% 20$ the $\% 20$ Future $\% 20$ of $\% 20$ Supply $\% 20$ Chains.pdf

7. http://www.pwc.com/GlobalSupplyChainSurvey2013

\footnotetext{
6 http://2014.internationaltransportforum.org/supply-chains-future\#sthash.KtoyZRgG.dpuf

7 www.pwc.com/GlobalSupplyChainSurvey2013
} 
8. http://www.sedexglobal.com/wp-content/uploads/2011/06/Sedex-Briefing-Future-Supply-Chain-Q32014-Final1.pdf

9. https://www.mhi.org/publications/report\#download; 2014 MHI Annual Industry Report - Innovations That Drive Supply Chains.

10. Lambert D.M., Cooper M.C., Pagh J.D., Supply Chain Management: Implementation Issues and Research Opportunities, The International Journal of Logistics and Management, 1998, 9 Issue 2.

11. Leonard D., Swap W., When Sparks Fly: Harnessing the Power of Group Creativity, Boston: Harvard Business School Press, 1999.

12. Mentzer J., DeWitt W., Keebler J., Min S., Nix N., Smith C., Zach Z., Defining Supply Chain Management, Journal of Marketing, Vol. 22, No. 2, 2001. http://dx.doi.org/10.1002/j.2158-1592.2001.tb00001.x

13. MIT Sloan Management Review and The Boston Consulting Group, Sustainability's Next Frontier, 2013, http://sloanreview.mit.edu/projects/sustainabilitys-next-frontier

14. Oliver R.K., Webber M.D., Supply-chain management: logistics catches up with strategy, In: M. Christopher, ed. Logistics: The strategic issues, London: Chapman \& Hall 1982.

15. Pramatari K., Collaborative supply chain practices and evolving technological approaches, Supply Chain Management: An International Journal, Vol. 12, No. 3, 2007.

16. Serdarasan S., A review of supply chain complexity drivers, Computers and Industrial Engineering, Vol. 66, No. 3, 2013. http://dx.doi.org/10.1016/j.cie.2012.12.008

17. Tang C., Tomlin B., The power of flexibility for mitigating supply chain risks, International Journal of Production Economics, Vol. 116, 2008. http://dx.doi.org/10.1016/j.ijpe.2008.07.008

18. Tang C.S., Perspectives in supply chain risk management, International Journal of Production Economics, Vol. 103, 2006.

http://dx.doi.org/10.1016/j.ijpe.2005.12.006

\section{Supply Chain Relationships in the Context of Innovative Processes}

Abstract. The paper deals with the issue of Supply Chain Management in the context of relationships between its members and possible innovations. It analyzes the dominating challenges in SCM and the impact they have on trends and future solutions. Supply chains in the future have to be more flexible and adaptive in order to be able to overcome problems stemming from complexity and increased risks. The analysis of secondary data leads to a conclusion that the future of SCM will be shaped by Big Data and technologies using them, knowledge management and talent scarcity avoidance as well as taking up innovative solutions in Green Supply Chain Management.

\section{Relacje w lańcuchach dostaw w kontekście działań innowacyjnych}

Abstrakt. Artykuł podejmuje kwestię zarządzania łańcuchami dostaw w kontekście relacji między jego członkami i możliwymi innowacjami. Analizuje dominujące wyzwania w SCM i wpływ jakie mają one na przyszłe rozwiązania i trendy. Łańcuchy dostaw w przyszłości muszą być bardziej elastyczne i adaptacyjne aby być w stanie rozwiązać problemy wynikające z rosnącej złożoności i zwiększonego ryzyka. Analiza danych prowadzi do wniosku, że przyszłość SCM będzie kształtowana przez Big Data i technologie wykorzystujące te dane, zarządzanie wiedzą i unikanie niedoboru uzdolnionych pracowników, a także podejmowanie innowacyjnych rozwiązań w zarządzaniu zielonymi łańcuchami dostaw. 